\title{
Cost Analysis in Indonesia Open University Post Graduate Program
}

\author{
Taufani C.K. \\ Universitas Pendidikan Indonesia \\ taufani@upi.edu
}

\author{
Tita Rosita \\ Universitas Terbuka \\ tita@ut.ac.id
}

\begin{abstract}
The aim of this study is to find out student cost spending in distance learning program due to financing plan in Open University post graduate program. Cost spending is related to unit cost term which is consists of fixed cost, variable cost, and opportunity cost. To analyze the cost spending we use the location of Distance Learning Unit Office Service as location approach i.e island based. The population of this study are all of students of Open University Post Graduate Program (OUPGP) and using sample size as 107 students by using proportional random sampling. This research using descriptive method with quantitative approach and apply SPSS software to crosstabs analyze. Based on the results of the study with 7 island as a sample. Expenses remain for distance learning post graduate program are relatively equal, the highest costs incurred students to pay tuition, while the lowest cost incurred to pay the initial registration in $1^{\text {st }}$ semester. While the costs associated with opportunity cost, students do not feel deprived of the opportunity due to lectures conducted online and face-to-face on Saturday-Sunday. For crosstabs analysis results, showed that OUPGP location based on the island, mileage, as well as students majoring in program taken effect on fixed costs, but those three things (OUPGP) location on the island, mileage, and majors that taken by the student do not affect the variable costs.
\end{abstract}

Keywords: Cost analysis, open university, post graduate program financing

\section{INTRODUCTION}

The availability of higher education in a country is one of main criteria for quality evaluation of models for financing higher education. If the availability of higher education increases, it is understood that the model for financing is better because it allows greater opportunity to prospective students [1]. Distance learning program is an education process without limiting walls of the school (education without walls). Previous research conducted by Tian Belawati and Durri Andriani [2], explained that the cost of distance education is determined by both the type of media being offered and the number of students served. Costs for the provision of distance education including the cost of institutional and personal expenses (incurred by students). The Open University (OU) for the largest proportion of the cost is for institutional learning and education (56\%), followed by public administration (41\%). In terms of personal expenses, tuition fees paid by students to study at UT is lower than the conventional university. The research results provide a general description, but still need to identify and elaborate kind of cost and factors that drive the cost (cost driver), especially in Post Graduate Program [3].

Based on previous research found that students requires a lot of expenses in 2 last semesters than the other half, both in terms of fixed costs (fixed cost) and cost variable (variable cost). Meanwhile, related to the cost of opportunity, students feel not lose the opportunity to work and earn a living while attending classes at the program, because the college system is online and face-to-face tutorials is held on Saturday and Sunday does not disrupt their work schedules [3].

To encourage the previous studies related to the identification of the costs in Post Graduate Program, is worth to exploring further related how the influence of geographical location (distance) and the type of education that is taken by students to expenses during his education periods. The research questions are about: (1) the amount of fixed cost / fixed costs, variable costs / variable costs, as well as the opportunity cost for postgraduate students while they following the distance learning program, (2) the influence of the location and the distance to the fixed cost and variable cost. Hopefully, the benefits of this research is to guide in planning education funding pattern tailored to each region, especially in post graduate distance learning program.

This study identify whether the location in Indonesia region cause cost differentiation in open university post graduate program.

\section{THEORETICAL BACKGROUND}

Cost of education includes the total cost which covers fixed cost and variable cost, unit cost per course or per pupil / student, average cost and marginal cost. Each of these types of costs have different characteristics [4]. Furthermore, cost of education includes also concern about the total cost which covers fixed cost and variable cost, unit cost per course or per pupil / student, average cost and marginal cost. Each of these types of costs have different characteristics. According to Rahardja and Manurung [5], the fixed costs are costs that the amount does not depend on the amount of production, for example, the cost of capital stems, salaries, and still to be incurred in the same amount at the time the company does not produce $(\mathrm{Q}=0)$. 
Pindyck and Rubinfield [6] argued that the fixed costs are costs that can not be varied with the level of output and can be eliminated if the company is closed (omitted). Meanwhile, according to Samuelson and Nordhaus [7], fixed costs are overhead costs or sunk costs due to be paid regardless of the firm produces or not, and does not change even though the output is changed (constant).

Meanwhile, according to Nafarin [8] says that variable costs are costs which amount to change in line with changes in the volume of activity but the cost per unit volume of activity has not changed despite the change. According to Samuelson and Nordhaus [7], variable costs are costs that change according to the amount of output, wherein when the output $=0$, variable costs (VC) are the number 0 . Pindyck and Rubinfield suggest that variable costs are costs that vary according with variable output [6].

Rahardja and Manurung [5] said that the opportunity cost is the opportunity to obtain something missing for choosing other alternatives. According to Harsono [9], the opportunity cost of the benefits is sacrificed at the time of choosing one among several alternative opportunities to obtain income benefit or advantage. Pindyck and Rubinfield [6] suggests that the opportunity cost or opportunity cost is the cost that comes from the opportunities missed by not putting resources into its highest value use. Meanwhile, according to Samuelson and Nordhaus [7], the opportunity cost is the loss caused by the determination of the alternative choice in scarcity is forcing many human sacrifice alternative activities, which in fact has led to the loss of the opportunity to work on something else.

The frameworks of this study are as follows:

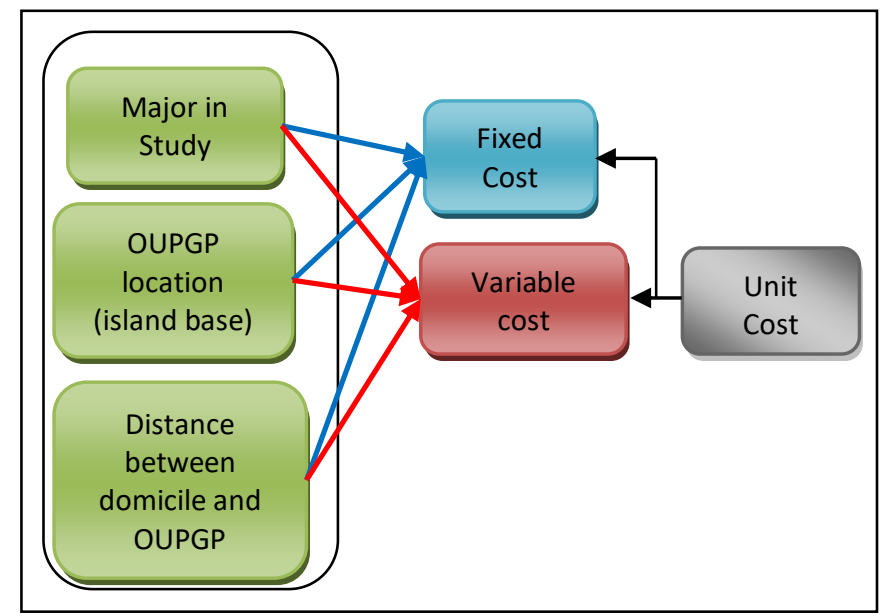

Figure 1. Research Framework

\section{RESEARCH METHOD}

Research conducted at OUPGP in Java, Sumatera, Bali, Boneo, Maluku, Nusa Tenggara Indonesia. The populations of this study were all students of the Open University's Post
Graduate program. Cross tabulation method uses statistical tests to identify and determine the correlation between variables. According to Santoso and Tjiptono [10], crosstab study (cross tabulation) presents data in the form of tabulation that includes rows and columns. Thus, crosstab characteristic is the presence of two or more variables that have a relationship descriptive data for presentation crosstab are generally qualitative data, in particular the nominal scale.

\section{RESULTS AND DISCUSSION RESEARCH}

Total questionnaires distributed are 107 questionnaires, which is made up fixed costs and variable costs. Futhermore, the amount of questionnaires and respond rate attain $83 \%$. The results of the data processing shows that for the Sumatra island, the highest average cost that students pay is for tuition fee, while the lowest average cost is for admission test. The highest average variable cost of financing is miscellaneous, while the lowest average cost is for equipment maintenance.

For Java, the highest average cost is for student tuition payments. The lowest average cost is for admission test. The highest average cost of variable cost is for household expenses, while the lowest average cost that is for online courses per semester.

In Bali, the highest average cost is for student tuition payments. The lowest average cost is for admission test. The highest average costs of variable cost is for meal and snacks, while the lowest average cost that is for stationary purchasing

Bali Island is highest average cost for payment of student fees, while the lowest average cost that is the cost of admission tests/ administration. The variable expenses, the highest average cost that is the cost of meal / snack, while the lowest average cost that is the cost of the purchase of stationery (including printer ink, paper, etc.).

For Borneo data showed that the highest average fixed costs for student is tuition payments and the lowest average cost is for New Student Orientation activities (NSOA). The highest variable costs concluded that require of a lot of transportation costs for the completion of the academic and administrative to OUGPP office from student's domicile. The lowest average variable cost is for stationery (including printer ink, paper, etc.) purchasing.

Data from Maluku Islands showed the highest average fixed cost is student tuition payments. The lowest average fixed is for of BTR 1 and BTR 2 (BTR is On site Thesis Guidance). Further the highest average variable cost is for transportation in completion of the academic and administrative process (transportation expenditures from student domicile to OUGPP office). The lowest average variable costs in transportation costs for the completion of the academic and administrative in 3rd semester.

In Nusa Tenggara islands the highest average fixed costs is for graduation ceremony preparation, while the lowest average 
fixed cost is for face-to-face tutorial. Associated with the variable costs, the highest average variable costs is for meal/ snack. In Sulawesi island the highest average fixed cost is for tuition fees, while the lowest average variable cost is for admission test. The highest average of variable costs is transportation costs, while the lowest average variable cost is for equipment (laptop, printer, etc.).

Based on the results of a study to determine the opportunity cost of through Crosstab analysis using SPSS version 16 showed that the island of Sumatra, Nusa Tenggara, Bali Island, Maluku, Borneo, and Java is in the category 3, while Sulawesi island include in category 3 and 4 . Category 3 mean-middle cost average and category 4 mean high cost average.

Further descriptions of the influence of certain aspects of the charges are as follows:

a) Effect of OUPGP on Variable Cost: there is no the influence of the island's location to the fixed cost incurred students accepted.

b) Effect of Location of OUPGP Island Variable Cost Issued Against Students Hypothetical calculation result shows that there is influence of the island's location OUPGP to the variable cost incurred students rejected.

c) The effect of distance from the house to the campus OUGPP the magnitude of student expenditure fixed cost. Hypothesis testing results indicate that there are significant distance from the house to the campus UPBJJ against fixed cost incurred students accepted.

d) The effect of distance from the student domicile to the campus OUGPP against massive spending student variable cost. Hypothesis testing results indicate that there are distances from the student domicile to the OUGPP office to affect variable cost incurred students.

e) The effect of the majors are taken students to the amount fixed cost expenditures students. Hypothesis testing results showed that there is no influence student majoring taken against the fixed cost incurred students accepted.

f) The effect of student majoring taken against massive spending student variable cost: Hypothesis testing results showed that there is influence student majoring taken against variable costs incurred students rejected.

The results of this study identify that location of education facility center in distance learning not related to cost expenditures especially relate to variable cost [11]; [12], [13]. However, in completing post-graduate education, students need to perform activities carried out in centers of educational services, such as counseling, registration, exams and graduation. This will cause locations with consequent education increased. However, costs when compared to conventional college, postgraduate study at the open university still more efficient. This is partly due to almost no opportunity cost to be sacrificed by the student. [14] [15] Further, in the context of increased participation of higher education, post-graduate courses by distance learning approach can overcome the constraints of education financing. [16] [17]. In the context of financial planning education, the results of this study can be used by prospective students to plan the needs education expenses in accordance with prospective students' domicile. Financial planning becomes an important part in the success of education, especially at the postgraduate level [18]

\section{REFERENCES}

[1] Mlinaric, Danijel; Bitanga, Iva. International OFEL Conference on Governance, Management and Entrepreneurship: 10081027. Zagreb: Centar za istrazivanje i razvoj upravljanja d.o.o. (Apr 2015)

[2] Belawati, T, Andriani, D., 2014."Sistem pendidikan terbuka dan jarak jauh: Suatu reformasi pola pikir",Technical paper presented at theSeminar Pendidikan Jarak Jauh Dalam Reformasi Pendidikan (Seminar on Distance Education in Educational Reform), Graduation I-2014 Universitas Terbuka. 2014.

[3] Rosita, Tita, 2015. Pembiayaan Pendidikan pada Universitas Terbuka. Jakarta: Universitas Terbuka.

[4] Fattah, Nanang. 2009. Manajemen Keuangan Pendidikan. Bandung: Alfabeta.

[5] Raharja, Pratama dan Mandala Mnurung. 2006. Teori Ekonomi Mikro: Suatu Pengantar (Edisi 4). Jakarta: Lembaga Penerbit FEUI.

[6] Pindyck, Robert S. \& Daniel L. Rubinfeld. 2009. Mikroekonomi Jilid 1, Edisi Keenam (terjemahan). Jakarta: Indeks.

[7] Samuelson, Paul A. dan William D. Nordhaus, 2001. Macroeconomics. Seventeenth Edition. McGraw-Hill Higher Education.

[8] Nafarin, M. (2004). Penganggaran Perusahaan. Jakarta: Penerbit Salemba Empat.

[9] Harsono. 2007. Pengelolaan Pembiayaan Pendidikan. Sleman: Surayajaya Press.

[10] Santoso, Singgih dan Tjiptono. 2001. Riset Pemasaran Konsep dan Aplikasi dengan SPSS. Elex Media Komputindo, Jakarta.

[11] Rumble, G. (1997). The cost and economics of open and distance learning London: Kogan Page Ltd.

[12] Jung, I. (1994). Improving the economics of budget allocation in distance education: A case study of Korea Air and Correspondence University in G. Dhanarajan et al (eds.) Economics of distance education: Recent experience, pp. 117-127. Hong Kong: Open Learning Institute Press.

[13] O'Lawrence, Henry.2007. An Overview of the Influences of Distance Learning on Adult Learners. Journal of education and human development. ISSN 1934-7200. Vol.1 Issue 1. California State University

[14] Naidu, C.G. (1994). Some economic aspects of conventional and distance education systems in India. In G. Dhanarajan et al (eds.) Economics of distance education: Recent experience, pp. 58-73. Hong Kong: Open Learning Institute Press.

[15] Perraton, H. (1994). Comparative cost of distance teaching in higher education: Scale and quality in G. Dhanarajan et al (eds.) Economics of distance education: Recent experience, pp. 19-30. Hong Kong: Open Learning Institute Press.

[16] Ruth, Stephen \& Min Shi. 2002. Distance Learning in Developing Countries:

Is Anyone Measuring Cost-Benefits? Online Journal of Distance Learning Administration, Volume V, NumberIII, Fall 2002. State University of West Georgia, Distance Education Center. 


\section{$\triangle$ ATLANTIS \\ PRESS}

Advances in Economics, Business and Management Research, volume 14

[17] Tsang, M.C. (1988). Cost analysis of the cost-effectiveness of CAI and factors associated with each successful implementation in higher education. AEDS Journal, 15 (1), pp. 10-22 